\title{
PROJECT MUSE*
}

\section{How to Cure Self-Deception: An Augustinian Remedy}

Shawn D. Floyd

Logos: A Journal of Catholic Thought and Culture, Volume 7, Number 3, Summer 2004, pp. 60-86 (Article)

Published by Logos: A Journal of Catholic Thought and Culture DOI: https://doi.org/10.1353/log.2004.0025

$\Rightarrow$ For additional information about this article https://muse.jhu.edu/article/170323 
Shawn D. Floyd

\section{How to Cure Self-Deception}

\section{An Augustinian Remedy}

Many Philosophers suppose at least some of our beliefs are products of self-deceptive thinking. ${ }^{1}$ Yet the acknowledgment that selfdeception occurs raises a worry rarely addressed in the contemporary literature: how can a person know that he or she is not self-deceived? Self-deceived persons routinely operate under the view that a belief or set of beliefs of theirs is true when in fact it is false. Self-deception, however, involves more than being mistaken about some belief. It occurs partly as a result of wanting something to be the case. ${ }^{2}$ Understood this way, self-deception is a product of the agent's desire - particularly the desire that something be true in the face of contradictory evidence. What is worrisome about desires of this sort is not their potential to generate isolated instances of selfdeception. The worry, rather, is that what people will or desire may produce patterns of belief formation that undermine their ability to weigh evidence, assess claims, and evaluate behavior (especially their own). If people's beliefs about themselves are shaped by unreliable doxastic practices, then how could they know whether they are selfdeceived? Their self-understanding may be shaped by beliefs that are themselves self-deceptively produced. 
Saint Augustine worries over a similar problem. Unlike many contemporary treatments of self-deception, however, his approach to the subject is circumscribed by his theological commitments. For Augustine, self-deception is a result of sin and its effects on the mind. Consider a passage that occurs in book ten of Augustine's Confessions. There, he notes how pride - manifesting itself as a love of others' praise and admiration - motivates his actions in covert ways:

For I cannot easily know how far I am clean from this disease [of pride], and I am in great fear from my secret sins — sins that Your eyes see, though mine do not. For in . . . other kinds of temptation I have some power of examining myself, but in this almost none. ${ }^{3}$

Augustine can combat most of the temptations to which he is vulnerable. Pride, however, presents a different kind of obstacle: it blinds him to the moral deficiencies of his choices and gives him an embellished sense of goodness. In short, pride makes him appear to himself better than he really is. Augustine acknowledges that he is vulnerable to pride's effects and asks God, "does this remain the real truth - that I deceive myself and neither think nor speak the truth in your sight?"4

Augustine appears to have the resources for addressing this worry. Earlier in book ten, he suggests that charity, or love for God, facilitates self-understanding by illuminating those desires and motivation that lie hidden in the human heart. ${ }^{5}$ This suggestion, however, is not one that Augustine explains in detail. Fortunately, he has plenty to say about charity in other texts. We can therefore go beyond the confines of the Confessions in considering how the appeal to charity might solve the problem of self-deception. Furthermore, Thomas Aquinas, who systematized much of Augustine's thought, illuminates charity's importance and explains its connection to other virtues crucial to self-understanding. I will draw from these sources 
in order to elucidate Augustine's view of charity and explain how it might solve the problem of self-deception as I have described it. I do not claim the proposed solution is precisely the view that Augustine held. I believe, however, his views allow for such a solution.

First, I will present Augustine's view of sin and its effects on our thinking. For him, self-deception is a kind of cognitive distortion resulting from sinful behavior. Any discussion of self-deception will therefore benefit from his account of sin and its cognitive effects. Next, I will discuss Augustine's view of self-deception in more detail, and then I will elucidate his view of charity and demonstrate its relevance to solving the problem of self-deception. I also will supplement Augustine's view by considering additional sources in which charity is a subject. In doing so, I will excavate the kind of solution Augustine may have had in mind. Last, I will entertain some objections to the proposed solution.

\section{The Effects of Sin}

Augustine did not provide us with a systematic account of selfdeception or attempt to distinguish it from related phenomena such as wishful thinking and delusion. His account occurs within the context of discussing how sinful behavior impacts our self-understanding. This subject is relevant to recent work on sin's noetic effects, a central thesis of which is that sin affects not only the will but also one's cognitive aptitudes. ${ }^{6}$ For Augustine, the proper exercise of one's intellectual capacities depends in part on one's moral behavior and its resulting dispositions. In short, moral virtue is necessary for intellectual excellence. Sinful actions, on the other hand, not only destroy moral virtue but also undermine one's ability to understand oneself, God, and the nature of goodness. Because Augustine thinks there is an important connection between sinful behavior and selfunderstanding, I will briefly sketch his view of sin before discussing its role in self-deception. 
Augustine describes sin as a free act of will whereby one turns from God, the highest and immutable good, to some created thing, the goodness of which is deficient by comparison. ${ }^{7}$ The "turning away" to which he refers may seem mysterious to those unfamiliar with his account of the will. For this reason, we should call attention to those aspects of his account that are relevant to the subject of sin. One must proceed carefully. Augustine's account of "will" is somewhat opaque because he implements the term in a variety of ways. ${ }^{8}$ On many occasions, however, the will denotes a power through which human beings regulate their actions, make choices, and perform what we customarily take to be "acts of will." This is the understanding of "will” that I will be using.

Augustine does not think the will operates spontaneously or independently of other faculties. Rather, it acts for the sake of an antecedently perceived object. For "only something that is seen can incite the will to act," and what one wills “must be brought to one's attention from outside through the bodily senses or enter one's mind in some obscure way." 9 This point deserves clarification. The will neither inclines to just any perceived object nor is impartial to the various ends human beings tend to pursue. As Augustine understands it, the will is an appetitive power that inclines to what a person conceives as good or conducive to happiness. ${ }^{10}$ We might think of the will as a power responsive to the rational part of the soul, a function of which is judging things with respect to their goodness (where a thing's goodness will be determined, in part, by its ability to foster and sustain happiness). Of course, a desired object may not have the value an agent ascribes to it. Immoral habits, poor education, and other factors can contribute to an impoverished understanding of what is truly good. Nevertheless, agents will be drawn to the object in question because they think it is good and able to facilitate happiness.

Augustine's reasons for embracing this view are rooted primarily in his Christian convictions. He agrees with his Greek predeces- 
sors that human beings have a native inclination to happiness. The point of that inclination, however, is to draw us to God. Because God is perfect goodness, it is in him that we find true happiness. Thus Augustine claims that God has created in us a desire for him, and "our hearts are restless until they rest in [him]." 11 Occasionally, however, a person will look to some created thing as a source of value and choose it at the expense of superior alternatives. Augustine therefore warns his readers of the enticement of earthly goods, the desire for which blinds us to their transitory quality and inability to make us truly happy. ${ }^{12}$

If God is the sole source of true happiness, why do we look elsewhere for satisfaction? The mutable nature of created things would seem to preclude them from satisfying us in any enduring way. In addressing this question, Augustine often points to our inordinate desires that, because of their excessive and misdirected nature, prompt us to behave badly. ${ }^{13}$ Yet he does not think those desires by themselves provide an adequate explanation for sin. Human beings are free, and freedom requires that we have the power to resist those influences that are causally relevant to action. If we cannot resist them, then we cannot be morally culpable for yielding to them. ${ }^{14}$ Therefore, Augustine says that we are "free not to succumb to the allure of inferior things." 15 Of course, if we can resist inordinate desire, then why do we fail to do so? Augustine's strategy in dealing with this problem is to call attention to the way human beings disregard or neglect God's goodness. Sin is not simply a matter of the will being unduly influenced by passion. It results from "neglecting to receive the commandment, neglecting to obey it, or neglecting to persevere in the contemplation of wisdom."16 Understood this way, sin has a cognitive component; it involves a failure to judge in accord with God's goodness, which is the only appropriate standard in matters of practical reason. ${ }^{17}$ By failing to consider that standard, our deliberations about what procures happiness become careless or hasty. We allow ourselves to be distracted by short-term pleasures 
and, in turn, make choices that hinder moral growth. When explaining why we fail to will as we should, we must consider not only the desires that distract us from what is good, but also the intellectual failures to which poor choices correspond.

When Augustine defines sin as a "swerving of the will," he is describing an act whereby we neglect God's goodness for the sake of an inferior object of satisfaction. ${ }^{18}$ If we persist in neglecting God's goodness, we may become disposed to making poor judgments. Our choices will give way to habits whereby we routinely make decisions on the basis of a distorted view of goodness. Worse yet, we may come to believe we are good just in virtue of choosing in accord with that view. According to Augustine, we are all vulnerable to this sort of self-deception. We are all beset by the tendency to create our own source of happiness and to believe there is no other standard to which we are subject. This deception may run so deep that we may not detect it even after careful selfexamination and reflection. In other words, sinful behavior will undermine our ability to judge whether we are unduly influenced by a deficient standard of goodness.

\section{Augustine on Self-Deception}

In one of his early commentaries on Genesis, Augustine provides an account of the Fall in which self-deception is central. In the account, Augustine says that Adam and Eve's sin was prompted by an unreasonable self-love and the belief that they could rule themselves. ${ }^{19}$ Predictably, they behaved as if they could make moral judgments independently of God's instruction. ${ }^{20}$ Note here what Augustine takes to be sin's effects on Adam and Eve's self-understanding: their love for created things (particularly themselves) drove them to "claim for themselves what they [were] not," namely, autonomous legislators who could create their own moral universe. ${ }^{21}$ Through their unnatural self-love, they believed they could be good apart 
from God, as evidenced by their rebellion and their subsequent attempt to blame God for their error. ${ }^{22}$ Through the transmission of original sin, these self-deceptive tendencies were passed on to all human beings.

Regardless of whether one fully accepts the aforementioned narrative, Augustine seems right in his general contention that selfdeception is a ubiquitous phenomenon. Recent studies in social psychology seem to vindicate this view. According to those studies, human beings are natively inclined to deceive themselves through self-serving attributions and comparisons. ${ }^{23}$ Such evaluations are often due to an "attributional egotism" 24 whereby they credit themselves for good outcomes and refuse responsibility for bad ones. Some of the ways people deceive themselves may seem morally innocuous, say, when they consider themselves to be more intelligent or adept at certain skills than they really are. But people also rationalize unethical behavior, deny their complicity in criminal acts, or minimize their responsibility for others' suffering. In doing so, they invent a reality in which they are morally blameless and - in the process - distort the truth about themselves.

Due to the pervasiveness of self-deception, Augustine is suspicious of any claim we might make to moral goodness. Even appeals to our meritorious deeds will be suspect. Actions we believe are praiseworthy can be compromised by self-seeking motives. Consider how we take pride in our moral accomplishments or seek the approval of others by performing seemingly good acts. Augustine addresses this precise concern when admonishing fellow Christians to guard themselves against the pride that emerges from commendable actions:

Faithfully interrogate your own souls [in order to determine] whether you have not been unduly puffed up by your integrity, continence, and chastity; and whether you have not been desirous of human praise that accompanies these virtues, that you have envied those who possessed them. ${ }^{25}$ 
Actions are not good simply because they manifest external signs of merit; they must be motivated in the right way. Apart from motive, one cannot discriminate between virtuous acts and those driven by self-serving concerns:

See what great works pride does. [Consider] how much alike, how much as it were upon a par, are the works [pride] does and those of charity. Charity feeds the hungry, and so does pride: charity, that God may be praised, pride, that itself may be praised. Charity clothes the naked, so does pride. Charity fasts, so does pride, charity buries the dead, so does pride. ${ }^{26}$

Unfortunately, it is difficult to determine just what one's motives really are. Human beings are "a great deep," and the "hairs on [their] heads are easier to number than the affections and movements of [their] heart[s]."27 Elsewhere, Augustine says that the human heart is an abyss that "cannot be reached or comprehended." 28 These passages are not just applicable to the hidden nature of others' motives. The human heart is a mystery especially to itself. ${ }^{29}$ One could examine oneself in order to determine whether one is unduly motivated by self-serving concerns. Such an examination, however, is not likely to yield self-understanding because one's motives are so inscrutable. In reflecting on this theme, Paul Weithman notes that "pride has so pernicious an effect on human character precisely because it flourishes in the dark, artfully playing a background and supporting role in the performance of wrong actions." ${ }^{30}$ In light of these considerations, it is not surprising that Augustine doubts his own ability to recount his conversion in a truthful way. ${ }^{31}$

Just as quickly as Augustine raises this worry, he poses a solution_-or at least the makings of one. In book ten of Confessions, he suggests charity can assuage doubt and enable us to know ourselves. In illuminating this point, Augustine first considers charity's effect on his readers: "When they hear me confessing of myself[,] [h]ow do they know whether I speak the truth?" Conversion involves an inte- 
rior change that cannot "be pierced with the eye or ear or mind."32 Thus Augustine's readers will be unable to tell whether his story is an accurate portrayal of an internal change or a fabrication. Yet he insists, "the charity by which they are good tells them that in my confession I do not lie about myself; and this charity in them believes me."33 Augustine's readers are not simply being charitable by assuming his account to be true. Rather, their love of God enables them to grasp the truth of what he says.

Charity plays a similar role in allaying Augustine's self-doubt. In chapter six of the same book, he says pride renders him incapable of determining whether his actions toward others are moved by love of neighbor or a covert desire for praise and recognition. It seems as if his actions are driven by a love of neighbor; yet there could be desires of a darker, more clandestine sort motivating him. Immediately following his admission of self-doubt, however, he says to God,

I know with utter certainly that I love you. For you have stricken my heart with your word and I have loved you. And indeed, heaven and earth and all that is in them tell me wherever I look that I should love you. ${ }^{34}$

Despite his inability to determine what motivates his actions, Augustine acknowledges an abiding affection for God. It is significant that his admission of self-doubt and profession to love God occur in such proximity. For these passages provide a context in which we can surmise Augustine's solution to self-deception. That solution, he says, will not be a product of his own reflective ability, but a matter of divine disclosure. He says, "what I know of myself I know through the shining of your light; and what I do not know of myself, I continue not to know until my darkness shall be made as noonday in Your countenance." ${ }^{35}$ Even with respect to those motives that remain hidden, he looks to God "until what is damaged in me is repaired and made perfect, to the attaining of that peace that the eye of the proud knows not."36 
Charity, then, provides Augustine insight into his actual motives, thereby enabling him to make a more accurate assessment of them. Regrettably, he does not explain how charity accomplishes this task. I will address this issue. In doing so, I will draw not only from Augustine's work but also that of Aquinas's in order to show how charity might provide a remedy for the doubt over which Augustine agonizes.

\section{Aquinas and Augustine on Charity}

Augustine inherited from classical philosophy an account of the moral life in which the traditional virtues were central. In fact, his understanding of the virtues is not unlike that of his ancient predecessors: prudence is knowledge concerning what we ought to desire and avoid. Courage is the disposition whereby we do not fear misfortune. Temperance is the disposition whereby we are not swayed by wicked desires. Last, justice is the virtue whereby everyone receives what is owed to them. ${ }^{37}$ The cultivation of these virtues contributes to the perfection of one's nature and, in turn, enables one to achieve a more complete and happy life.

Besides these traditional virtues, Augustine also recognized three theological virtues: faith, hope, and charity. The inclusion of these virtues signals an important departure from the classical account. According to that account, virtues are habits one acquires through properly training the passions or the correct use of reason. Theological virtues, however, are not habits one acquires on one's own. They are dispositions God infuses into an agent. Because my interest is in Augustine's view of charity, I will not pursue his account of faith and hope. I do think, however, elucidating the nature of charity can at least suggest why Augustine thinks theological virtues are not simply moral supplements but essential traits of human goodness.

Augustine defines charity as "the motion of the soul toward the enjoyment of God for his own sake and the enjoyment of oneself and 
one's neighbor for the sake of God." 38 Elsewhere, he describes charity as a disposition through which one cleaves to God, who is the "unchangeable good, the proper and principle good for a human being." 39 Because God is the supreme good, he is the only thing one should love for its own sake. This does not mean one is prohibited from loving things other than God. As Augustine's definition suggests, we ought to love our neighbor because in doing so we are better able to enjoy God. ${ }^{40}$

This last claim can be misleading, for it seems as if Augustine advocates treating others as nothing more than a means to an end. This reading, however, does a disservice to Augustine, who wishes to discourage us from thinking true happiness consists in created things. Indeed, we ought to love our neighbors but not because of the benefits our relationship to them affords. Rather, we love them because they bear God's image and participate in his providential scheme. ${ }^{41}$ In doing so, however, we love them according to their place in a hierarchy of goods. Because created things have only a measured goodness, we should not love them as if they were the source of supreme value. When we love created things in this way, we become susceptible to those passions that distract us from our heavenly end. So long as God is the principle object of our love, we will not fall prey to those desires that tempt us to sin.

According to Augustine, then, charity is central to our own virtue. ${ }^{42} \mathrm{He}$ emphasizes the centrality of charity by describing it as nothing less than perfect virtue, of which the classical virtues are expressions: temperance is love giving itself entirely to God; courage is love enduring all things for God's sake; justice is love serving God alone; and prudence is love making good decisions about what facilitates beatitude. ${ }^{43}$ In this view, charity constitutes the virtues' foundation - the "common essential core" without which one cannot be completely happy. ${ }^{44}$ Due to his unsystematic treatment of the subject, Augustine's reasons for making charity foundational in this way are somewhat elusive. Aquinas, however, did much to elucidate 
Augustine's views. I will turn to Aquinas's view of charity in order to clarify the reasons for charity's expressed importance.

Like Augustine, Aquinas argues that charity is included in the definition of every virtue. He does not mean charity is identical to the other virtues. Rather, charity provides the condition through which the other virtues are perfectly realized. ${ }^{45}$ By way of an analogy, Aquinas notes the way in which prudence is included in the definitions of the moral virtues "from the fact that they depend on it." In order to cultivate justice, temperance, and courage, one must know what sort of actions will produce these dispositions, and prudence is that knowledge. But why think that charity is related to the other virtues in this way? Although knowledge of good and bad is a prerequisite for moral virtue, the idea that charity is necessary for complete virtue seems mistaken because there are people capable of virtuous acts who have no charity.

Aquinas addresses this objection in Summa theologica IIaIlae 23. Here, Aquinas defines virtue as a habit that disposes human beings to follow both reason and God's rule. ${ }^{46}$ By acquiring virtue, one can achieve the enjoyment of God for its own sake. ${ }^{47}$ Aquinas concedes, however, there are some goods not connected to the enjoyment of God ("for example, the welfare of the state"). Obtaining these goods is not beyond a person's natural aptitude and therefore does not require supernaturally infused habits. Still, Aquinas insists unless our actions are somehow connected to the enjoyment of God, we should consider them as having an imperfectly virtuous quality.

This last point deserves elucidation. Acts lacking charity are of two kinds: those that are in accord with the agent's lack of charity and those that are not. The first concerns acts one performs qua sinner. Actions of this sort might appear meritorious, but whatever laudable properties they seem to have are vitiated by those actions' self-serving motives. These actions are always sinful "even when [the sinner] clothes the naked, or does anything similar, and directs it to his unbelief as an end." 48 On the other hand, there are actions 
that - while not motivated by charity - are performed in virtue of one's naturally endowed good, which is never completely lost despite our fallen state. ${ }^{49}$ These acts are generically good insofar as they contribute to the improvement of human reason. They are not perfectly good, however, because they lack the order of charity; that is, they lack the motivation that directs one to the love of God. Even in the absence of charity, then, one can achieve some measure of virtue, although the virtue cannot receive its full expression or direct one to perfect happiness.

We find a similar, albeit less precise, account of virtue in the Augustinian corpus. Occasionally, Augustine suggests virtues unaccompanied by the love of God are in fact disguised vices: for "the virtues that [the soul] seems to possess . . . are rather vices than virtues so long as there is no reference to God in the matter." ${ }^{50} \mathrm{But}$ Augustine does not always describe pagan virtue in this way. Elsewhere, he mentions that the civic virtues of the Romans exhibited a "certain uprightness." For "though they had not the true piety towards the true God ... they did nevertheless observe a certain integrity of its own kind, which might suffice for founding, enlarging, and preserving an earthly commonwealth." ${ }^{51}$ In the absence of God's grace, however, good actions always will be tainted by motives that diminish their otherwise commendable nature. ${ }^{52}$

Not only does the absence of charity preclude the possibility of complete virtue, but it also precludes the acquisition of charity's accompanying gift, namely, wisdom. Medieval accounts of wisdom are varied. Most of them, however, tend to follow the Aristotelian view that the wise person understands the highest cause of things. By "highest cause," Aquinas means, roughly, the fundamental principle or causes according to which things are ordered. We can understand the idea of "highest cause" in one of two ways. First, the "highest cause" could refer to the basic principles that govern a specific field of inquiry. In this view, one is wise with respect to a particular discipline such as medicine or architecture. ${ }^{53}$ The wise person is 
acquainted with the foundational principles of these disciplines, and therefore knows what those disciplines are for (namely, health and a sturdy building, respectively) and can achieve the goals at which they aim. The second sense of "highest cause" is broader in scope. It refers to a theoretical grasp of the world's supreme or most universal causes. In other words, the highest cause denotes the world's most metaphysically basic realities. The person who grasps the highest cause and thereby understands the principles that govern the nature and movement of everything that exists is said to be wise. ${ }^{54}$

The preceding discussion of "highest cause" is central to wisdom construed as an intellectual virtue. Aquinas's interest, however, is wisdom as a gift correlative to charity. Wisdom in this sense is not an intellectual achievement; it is an endowment of the Holy Spirit. Those who have the gift of wisdom understand that God is the supreme cause of all things. ${ }^{55}$ They also comprehend God's nature and attributes, including his goodness. This aspect of wisdom-as-gift signals an ethical dimension that wisdom-as-virtue lacks. For knowledge of God's goodness enables the wise person to direct actions according to divine rules. ${ }^{56}$ Seen this way, the gift of wisdom comprises both theoretical and practical knowledge because it illuminates the standard according to which the wise person makes good judgments. 57

Because the gift of wisdom is inextricably linked to making good moral judgments, it cannot be had by those who engage in mortal $\sin .{ }^{58}$ By "mortal sin," Aquinas means a defective volitional state whereby one embraces some end or action that is contrary to the love of God. Mortal sin is particularly egregious because it destroys charity, the principle by which we are joined to God. Mortal sin separates a person from God and renders the person unable to receive the gifts that result from loving God with the love of charity. Aquinas concedes that wisdom understood as an intellectual virtue is compatible with mortal $\sin .{ }^{59}$ In other words, one could, in the absence of moral virtue, have wisdom in the Aristotelian sense of grasping 
the world's underlying metaphysical principles. ${ }^{60}$ As a gift of the Holy Spirit, however, wisdom presupposes charity. For this reason, Aquinas insists that although wisdom is a disposition of the intellect, its cause is in the will. ${ }^{61}$

\section{Charity, Illumination, and Wisdom}

Aquinas's account of charity can help us think more constructively about Augustine's own views. Obviously, their accounts will have similarities because Aquinas inherited many of his views from Augustine. Augustine's discussions of wisdom, however, focus primarily on its practical dimensions. In De trinitate, for example, Augustine says the wise person consults that which is changeless and eternal when determining a proper course of action. That person considers the "highest principles of divine justice" and lives in loving labor for God. ${ }^{62}$ In On Free Choice of the Will, Augustine describes these principles as "virtues' lights," the likes of which include "one ought to live justly; inferior things should be subjected to superior things; like should be compared with like; everyone should be given what is rightly his; . . one should not love corruption but incorruption."63 From these remarks it would appear that having wisdom consists primarily in consulting and making judgments in accord with God's law.

There are other differences between this account of wisdom and Aquinas's. For example, Augustine does not explicate wisdom as a discrete habit easily distinguished from other virtues. ${ }^{64}$ Nor does he make explicit its connection to charity. Nevertheless, I believe Augustine thinks, as Aquinas does, that the ability to make wise judgments depends on having a charitable will. In order to elucidate this connection, I will go beyond what Augustine says explicitly and tease out what his stated views imply.

According to Augustine, the wise person participates in wisdom by considering what is changeless and eternal. ${ }^{65}$ In doing so, the person shares in the very life of God, for to consult the principles of wis- 
dom is no less than "to participate in that which is self-existing" ( $u t$ sit participatio eius in idipsum). ${ }^{66}$ Contemplating wisdom's principles, then, will be indistinguishable from contemplating God's nature. Understanding God's nature, however, is not an ability one achieves on one's own. Like Aquinas's sense of gift, the ability is given to those who respond positively to God's grace and live according to his precepts. Thus Augustine thinks our grasp of wisdom's principles is due to God's illuminative power. ${ }^{67}$ What he means by "illumination" is a subject of some disagreement, and I will not attempt to sort out those disagreements here. For our purposes, it will be sufficient to highlight those uncontested features of illumination relevant to our investigation.

Briefly, Augustine thinks our judgments about the world are not judgments about which we can be certain unless there is an interceding power that confirms their truth. Consider the judgments based on what we hear or read. We cannot rely on the eloquence of a speaker to make truth known to us. We cannot depend on the clarity of an author's prose to demonstrate the veracity of his or her conclusions. There is nothing internal to these sources that can confirm the truth of the information conveyed. Our teachers may advise us to attend carefully to what they say, but "if there is [no one within us] to teach, vain is the sound [our teachers] make." 68 There is, however, a source of truth that exists within us and "presides . . . over the mind itself." 69 That source is God's illuminative power. In order to attain any knowledge at all, we must consult the power that Augustine describes as an "interior light" whereby God reveals the truth of what we hear and read. ${ }^{70}$ This theme is reiterated throughout Augustine's work. For him, all knowledge — including knowledge of wisdom's precepts - requires the assistance of an infallible mediator who confers truth on the human mind. ${ }^{71}$

It is crucial to note here that Augustine does not think of illumination simply as a matter of filling epistemological lacunas. Illumination has a crucial ethical component. In fact, moral goodness is a 
condition for illuminated wisdom, for "the wisdom of God . . is disclosed to anyone to the extent that he can apprehend it according to his good or evil will." 72 Having a good will, however, requires a person relinquish attachment to created things and cling to God as the source of beatitude. ${ }^{73}$ Only by loving God wholeheartedly can we discern the principles by which human beings become supremely blessed. ${ }^{74}$

This account of wisdom may raise the following worry. Obviously there are people who neither love nor seek God but nevertheless make good judgments on the basis of wisdom's principles. In an apparent response to this concern, Augustine acknowledges that a person who lacks wisdom would be unable to acknowledge that wisdom was something for which he or she ought to strive. ${ }^{75}$ Moreover, the light of wisdom seems to touch those who usually ignore moral principles, as evidenced by their moral indignation when wronged by others. ${ }^{76}$ From these observations, Augustine concludes even vicious people have some modicum of wisdom. This qualified position suggests having wisdom is not an all or nothing affair; it can develop over time, depending on “one's continued efforts to love well and treat others decently."77 Still, Augustine never retreats from the view that our awareness of moral principles is due to God's illuminative power "without which no one is able to come to wisdom nor to righteousness."78 Even though he concedes all human beings enjoy some measure of illuminated wisdom, he is clear that those who are most deserving of the term "wise" are those who love God and their neighbor as themselves. ${ }^{79}$

The idea that wisdom ultimately depends on charity can help us see how Augustine finds refuge from the fear of being self-deceived. First, consider why only charitable readers can apprehend the truth of Augustine's testimony. Augustine says those who believe the story of his conversion will be those whom charity "binds to itself." 80 The binding power to which Augustine refers is not the result of divine coercion. It is a result of the will's attraction to what is good simpliciter. As an appetite for what is good, the will naturally inclines to 
whatever the mind conceives of as valuable or choice-worthy. Thus Augustine often speaks of the charitable person as one whose will "cleaves to" or is bound to God. ${ }^{81}$ Those with a singular love for God are less likely to be distracted by inferior desires or tempted by things incompatible with his goodness. Because their minds are not clouded by excessive or misdirected passion, they will be able to apprehend the truth of Augustine's testimony, which God generously discloses to them.

Similarly, charity provides Augustine with a noetic clarity that makes self-understanding possible. As we saw earlier, sin's distorting effects make self-deception a constant worry. Even the mere possibility of being self-deceived can generate doubt about one's true motives. ${ }^{82}$ Yet Augustine does not capitulate to what might seem an inevitable skepticism. Instead, he confesses his pride and looks to God to illuminate aspects of his character that were previously hidden. ${ }^{83}$ The person who is preoccupied with ends contrary to God's goodness cannot enjoy the benefits of that illumination. We must love what God loves and seek happiness in him rather than in created things. Love of this sort will naturally produce a more acute awareness of our moral frailties. For not only does charity direct our attention to God's goodness, it produces humility and forestalls the tendency to exaggerate our own goodness. According to this view, then, the remedy for self-deception lies not in a person's own selfreflective capacities; it comes by way of a moral transformation made possible by charity. Perhaps it is for this reason Augustine begins the prologue of his commentary on St. John's first epistle by saying, "where there is humility, there is charity." ${ }^{4}$ And here we might add, "where there is charity, there is self-understanding."

\section{Objections}

I will now address some objections to the account I have presented. The first objection concerns what seems to be a lingering skeptical 
problem. Consider someone whose actions are allegedly driven by a love for God. Could those putatively charitable motives really be self-interested desires masking as religious affection? If we can be fooled into thinking our self-serving motives are good, then surely we can be fooled into believing our actions are driven by charity. I have no reason to doubt this sort of deception occurs. But the fact that we could be deceived in this way is no reason to dismiss the resources Augustine insists are available to us. In his view, God's illuminative power enables those who love him to distinguish exemplary motives from self-seeking ones. Of course, whether one accepts this claim depends on whether one believes Augustine's account of God and human beings. If that account is true, then it seems reasonable to suppose God could instill in us an ability to discriminate between genuine instances of charity and their imitators. The fact that some people are sometimes deceived in thinking their actions are driven by exemplary motives does not constitute a serious objection to Augustine's account. If it is true that God illuminates the minds of those who love him, then they will be able to make warranted self-appraisals concerning their real motives.

The second objection challenges the extent to which we must rely on God in detecting instances of self-deception, for it appears that people come to realize they are self-deceived without divine assistance. Although sin may incline us to deceive ourselves, it does not destroy our ability to remedy self-deception's effects through, say, scrupulous reflection and self-examination. There may be times when we need not look beyond ourselves when appraising our real motives. ${ }^{85}$ Of course, if we are capable of detecting all instances of self-deception, then sin's effects are more negligible than what the Christian tradition indicates. Perhaps, then, we should allow that we can sometimes (say, in innocuous cases) detect instances of selfdeception independently of God's help. In making this modest concession, however, the claim that we need God's help in determining whether we are self-deceived is weakened considerably. 
This objection and subsequent solution raise the following problem. Even if unaided human capacities are capable of detecting instances of self-deception, we have no assurance they are reliable in cases that really concern us. Consider cases in which a person's self-understanding is incorrigibly flawed due to excessive rationalization or a prolonged refusal to acknowledge real moral guilt. The annals of history are full of persons convinced of their exemplary character when in fact they were moral monsters, and no amount of argument or evidence could convince them otherwise. To say one's reflective capacities can detect self-deception in these cases seems to contradict a fair amount of evidence. Because the aforementioned cases are the ones that usually concern us, the fact that we can sometimes detect self-deception within ourselves cannot dispel the worry that we may still be deceived about matters of grave moral concern.

Moreover, the aforementioned objection seems to take a somewhat insouciant stance toward sin's noetic effects. Were we to take those effects seriously, it is doubtful we could trust the results of our own self-appraisal. Philosophers sometimes propose conditions that could forestall self-deception. For example, J. L. L. Shellenberg argues one might avoid self-deception as long as one's investigative procedures are (among other things) sufficiently scrupulous, honest, and informed by a love for truth. ${ }^{86}$ Who, however, can employ these standards consistently and without fail? The ability to do so presupposes a range of intellectual and moral virtues few people actually have. ${ }^{87}$ Scrupulous self-examination motivated by a love for truth is no doubt an activity we should all practice. But whether we are capable of doing so in a prolonged way is an open question.

In a recent essay that takes much of its inspiration from Augustine, Bas van Fraassen raises this precise point. He argues one can not prevent self-deception simply by being more scrupulous in investigating problems, weighing evidence, and entertaining solutions because "it is exactly [through] these processes that self-deception 
always finds its means." 88 Van Fraassen's subsequent comments deserve a more extensive citation:

For one selects, but not explicitly or consciously, what aspects to attend more closely; the weights to give to different bits of evidence are not "written into" that evidence but must be supplied by oneself; and the imagination . . . so active in directions pleasing to oneself, or alternatively frightening, servant of wishes and fears, is itself the flawed mother of the flawed queen of the world! Under these conditions, how shall we ever find a spot of safety, secure from the distrust of one's own opinion? ${ }^{89}$

When reflecting on matters important to us, we often conduct ourselves not with objective detachment but with a desire to satisfy our own interests. Thus we cannot rely on purely procedural methods when examining ourselves. Self-examination involves an affective component that may distort its results.

The response to the preceding objection may raise the following worry. If our self-reflective capacities are as tainted by sin as Augustine suggests, then (apparently) we cannot trust any putative solution that depends on them. In short, the problem of self-deception defies any solution of a philosophical nature, for the cognitive distortions caused by sin undermine the reliability of any solution generated by the intellectual capacities of fallen human beings. In my view, Augustine's treatment of self-deception provides at least a provisional response to this worry. If he is right about the extent of sin's cognitive effects, then self-deception's cure will not come by way of our own intellectual designs. It does not follow, however, that our resources for treating self-deception are exhausted. Self-deception's solution could originate from outside of the confines of human reason. Surely an awareness of our moral frailties and intellectual limits should encourage us to consider remedies to self-deception that may fare better than philosophical ones. 
Again, van Fraassen provides an interesting - and slightly different - perspective on this matter. He agrees that no philosophical theory can yield an acceptable solution to self-deception. Yet he goes on to argue that we must not renounce or reject all appearances or "confidence in one's own appreciation of the facts." 90 In other words, we cannot - and should not - deny those realities that appear certain to us. To do so is to capitulate to skepticism, to admit defeat. ${ }^{91}$ In order to preempt doubt's destructive results, we must exercise faith that our self-evaluations are right or at least near right. Just as we exercise faith when trusting the reliability of sense-perception, so we must exercise faith that our beliefs about ourselves are true. The practical affairs of life require that we do so. Admittedly, there is something of a gamble here because those beliefs could be false. For this reason, we must, by a concerted act of will, exercise courage "to sustain any appreciation of what there is." After all, if philosophy could a provide a solution to self-deception, "it would remove the role of courage altogether."92

Van Fraassen's account is admirably rich and is perhaps one of the most insightful pieces on self-deception I have come across. Yet I find this aspect of his account problematic. If we acknowledge our evaluative capacities are flawed, then how could we fully trust any belief produced by them? The issue here is not whether we should trust those capacities, but whether we would be able to if we thought them unreliable. Herein lies a crucial difference between sensebased beliefs and beliefs about ourselves. Even when we submit the former to Cartesianlike doubt, we invariably find ourselves undisturbed by the exercise. Outside of philosophy seminars and latenight coffee-house discussions, we tacitly embrace the reliability of our senses. On the other hand, we have good reason to think some of our self-evaluations are probably false (especially if we take seriously Augustine's view of sin's cognitive effects). If we were to make this concession, it would render us incapable of trusting any judgment we think innately suspicious or ill formed. For this reason, it 
seems unlikely we could courageously yield to the deliverances of those capacities we suspect are defective.

In my view, then, Augustine would not accept van Fraassen's solution to self-deception. In rejecting this solution, as well as standard philosophical solutions, Augustine does not bend to skepticism. He draws from the wellsprings of Christian theology and offers us a remedy that purports to cure self-deception with no residual uncertainty. I have argued that this remedy can be found in his appeal to charity. Although he does not explain in detail how charity cures self-deception, I hope to have provided an account that helps us understand what that remedy might look like. ${ }^{93}$

\section{Notes}

Unless otherwise indicated, translations of Augustine's texts are taken from The Nicene and Post Nicene Fathers of the Christian Church, vols. I-VIII, ed. Philip Shaff (Grand Rapids, Mich.: Eerdmanns, I 956).

I. Some philosophers dispute this claim by arguing that self-deception entails an irresolvable paradox. On this view, self-deception requires that people convince themselves that what they believe is not true. That is, they must convince themselves $x$ is true even though they believe $\sim_{x}$ is true. Seen this way, self-deception requires that one believe contradictory claims. Those convinced that self-deception occurs, however, naturally reject this formulation of the phenomenon. For a critique of this formulation, see Alfred Mele, Irrationality: An Essay on Akrasia, Self-Deception, and Self-Control (New York: Oxford University Press, 1987); Alfred Mele, "Real SelfDeception," Behavioral and Brain Sciences 20 (1 997): 9 I-1 02 .

2. Mele, Irrationality, I 25 .

3. Confessions, trans. F. J. Sheed (Indianapolis: Hackett, I 993), I 0.37.

4. Ibid.

5. Ibid., г о.3; г 0.6-10.7.

6. See especially Merold Westphal, "Taking St. Paul Seriously: Sin As an Epistemological Category," in Christian Philosophy, ed. Thomas Flint (Notre Dame: University of Notre Dame Press, 1990), 200-26; Stephen Moroney, The Noetic Effects of Sin: A Historical and Contemporary Exploration of How Sin Distorts Our Thinking (Lanham, Md.: Lexington Books, 2000); Alvin Plantinga, Warranted Christian Belief(Oxford: Oxford University Press, 2000), chap. 7.

7. Confessions, 2.6, 7.16; On the Free Choice of the Will, trans. Thomas Williams (Indianapolis: Hackett, I 993), 2. I 9, 2.20. 
8. For an account of Augustine's various uses of voluntas, see Scott MacDonald, "Primal Sin," in The Augustinian Tradition, ed. Gareth Matthews (Berkeley: University of California Press, I 999), i I 7.

9. On Free Choice of the Will, 3.25.

I o. Ibid., I. I4; Confessions, 2.5; The City of God, trans. Marcus Dods (New York: Random House, 1994), I 4.6.

I I. Confessions, I. I.

I 2. Augustine does not think created things lack goodness altogether. For him, created things are good to the extent that they exist or have being. The identification of being with goodness led Augustine, as well as many of his medieval successors, to embrace the view that created things increase in goodness as they actualize the capacities inherent in their nature. If a created thing had no goodness whatsoever, then it would not exist: "Therefore, as long as they are, they are good. Thus, whatsoever things are, are good" (Confessions 7. I 2). From this perspective, created things have a certain measure of goodness, albeit one that cannot rival God's unqualified goodness.

13. Confessions, 2.5; On Free Choice of the Will, 2. 19.

14. On Free Choice of the Will, 3. 18.

I5. Ibid., 3.25 .

I6. Ibid., 3.24 .

I 7. I am indebted to Scott MacDonald's insight here. He argues that the sinner's failure to consider God's goodness is central to explaining unprecedented sin. We cannot account for unprecedented sin in terms of a defective will because God's original creation contained no imperfection. Nor can we say the first sins had no explanation because doing so severs the continuity between sinful actions and the persons who commit them. We should explain sin in terms of a "cognitive failure" whereby primal sinners "failed to pay attention to the reason they had for loving God above all things, namely, their knowledge that God is the highest good" (MacDonald, "Primal Sin," I 20). I think this account is relevant in explaining sin at a more general level, and I am following it to some extent.

I 8. On Free Choice of the Will, 2.19; MacDonald's remark is helpful here: "We need, then, to think of the single act of will as having two faces; it is at once a turning toward and turning away, an embracing and abandoning." He refers to Augustine's own description of sin as involving "both a conversio and an aversio" (MacDonald, "Primal Sin," I I 9 ).

1 9. Two Books on Genesis against the Manichees, trans. Roland Teske, in The Fathers of the Church, vol. 84 (Washington, D.C.: Catholic University of America Press, I 99 I), 2.15.22.

2o. Ibid

21. Ibid., 2.26.40.

22. Ibid., 2.17.25.

23. For an analysis of these phenomena and a review of the relevant literature, see Moroney, The Noetic Effects of Sin, 90-97. 
24. M. L. Snyder, W. G. Stephan, and D. Rosenfield, “Attributional Egotism,” in New Directions in Attribution Research, vol. 2, ed. J. H. Harvey, W. J. Ickes, and R. F. Kidd (Hillsdale, N.J.: Erlbaum, I 978), I I 3 ; also quoted in Moroney, The Noetic Effects of Sin, 93.

25. The City of God, I . 28; Cf. Confessions, г ०.38.

26. Ten Homilies on the First Epistle of John, 8.9.

27. Confessions, 4. I 4 .

28. Exposition on the Psalms, 42 . I 2.

29. The Nature and Origin of the Soul, IV. I o. I am indebted here to John Rist, Augustine: Ancient Thought Baptized (London: Cambridge University Press, I 994), which alerted me to many of the passages cited in this paragraph. Westphal, "Taking St. Paul Seriously," 2 I 7 .

30. "Toward an Augustinian Liberalism," in The Augustinian Tradition, 3 I I .

3. Confessions, i 0.3 .

32. Ibid.

33. Ibid

34. Ibid., I 0.6. The word for love in this passage is amore rather than caritas. The use of this term, however, does not change what Augustine intends to convey. Note, for example, the way in which Augustine employs both terms in addressing God: o amor, qui semper ardes et numquam extingueris, caritas, deus meus, accende me! continentiam iubes: ad quod iubes et iube quod vis. The terms for love in this passage are synonymous. Other commentators agree Augustine frequently uses these terms interchangeably. Oliver O'Donavan, The Problem of Self-Love in Augustine (New Haven: Yale University Press, I 980 ), I I ; Rist, Augustine, I 50.

35. Confessions, г 0.5 .

36. Ibid., 10.38 .

37. On Free Choice of the Will, I . I 3 .

38. On Christian Doctrine, trans. D. W. Robertson Jr. (Upper Saddle River, N.J.: Prentice Hall, I 958), III. I о. I 6; Eighty-Three Different Questions, trans. David L. Mosher, in The Father of the Church, vol. 70 (Washington, D.C.: Catholic University of America Press, I 982), question 36 .

39. On Free Choice of the Will, 2 . I 9.

40. On Christian Doctrine, I.22.20.

4I. De vera religione, trans. John Burleigh (Philadelphia: Westminster Press, I 995), 46.88.

42. The City of God, I 5.22; On Christian Doctrine, I .27.28.

43. Of the Morals of the Catholic Church, I 5.25.

44. Rist, Augustine, I 73.

45. Thomas Aquinas, Summa Theologica, vol. 5 (Notre Dame: Ave Maria Press, i 997): IlaIIae 23.4 ad I .

46. Ibid., $23 \cdot 3$.

47. Ibid., $23 \cdot 7$.

48. Ibid., 23.7 ad I : quod actus infidelis, inquantum est infidelis, semper est peccatum; etiam si nudum operiat vel quidquid aliud huiusmodi faciat, ordinans ad finem suae infidelitatis. 
49. Ibid., IlaIlae 65.2.

50. The City of God, 19.25 .

5 I. The Letters of St. Augustine, I 38.3 . I 7.

52. For a helpful discussion of Augustine's view of pagan virtue, see Rist, Augustine, I $68-73$.

53. Aquinas, Summa Theologica, IIaIlae 45. I .

54. Ibid.; Thomas Aquinas, Summa Contra Gentiles (Notre Dame: University of Notre Dame Press, 1975) I: 2, 4.

55. Eleonore Stump, "Wisdom: Will, Belief, and Moral Goodness" in Aquinas's Moral Theory: Essay in Honor of Norman Kretzmann, ed. Eleonore Stump and Scott MacDonald (Ithaca: Cornell University Press, I 999), 48. I benefited from Stump's account of wisdom when writing this section.

56. Aquinas, Summa Theologica, IlaIlae $45 \cdot 3$.

57. Ibid., $45 \cdot 3$ ad 2.

58. Ibid., $45 \cdot 4$.

59. Ibid., 45.4 ad 2.

60. Stump, "Wisdom: Will, Belief, and Moral Goodness," 52.

6I. Aquinas, Summa Theologica, IlaIlae 45.2, 4.

62. On the Trinity, trans. Edmund Hill (New York: New City Press), 3. I.8 (3.2.8 in the Eerdmanns edition).

63. On Free Choice of the Will, 2. I 1.

64. Vernon J. Bourke, Wisdom from St. Augustine (Houston: Center for Thomistic Studies, University of St. Thomas, I 984), 55.

65. On the Trinity, 3. I.8 (3.2.8).

66. Ibid.

67. I am indebted here to Bourke's account, which emphasizes the moral dimension of divine illumination (Wisdom from St. Augustine, i I 8).

68. Sermons on St. John's First Epistle, 3. 13.

69. The Teacher, trans. Peter King (Indianapolis: Hackett, I 995), I I .38; Confessions, I I .6.

70. Confessions, 12.40 .

7I. Ibid., $4.15 ; 5.6 ; 10.40$.

72. The Teacher, I I.38 (emphasis mine); De Vera Religione, $3 \cdot 3$.

73. On Free Choice of the Will, 2.16.

74. Eighty-Three Different Questions, question 46.

75. On Free Choice of the Will, 2. I 5.

76. Confessions, 2.4 .

77. Bourke, Wisdom from St. Augustine, I I 6.

78. Treatise on St. John's Gospel, 35.8.3; On the Trinity, I 4. I 5.2 I . I am indebted to Bourke's book for calling these passages to my attention.

79. Eighty-Three Different Questions, 36.4 .

8०. Confessions, г 0.3 .

8I. De vera religione, г о. I 9 ; Confessions, 4 . I 0. 
82. Bas van Fraassen, "The Peculiar Effects of Love and Desire," in Perspectives on Self Deception, ed. Brian McLaughlin and Amelie O. Rorty (Berkeley: University of California Press, I 988 ), I 45 , I 52.

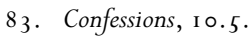

84. I am indebted to Rist's book for bringing this passage to my attention.

85. I thank Colleen McCluskey for raising this objection.

86. J. L. L. Schellenberg, Divine Hiddenness and Human Reason (Ithaca: Cornell University Press, 1993), 65-66.

87. For a thorough criticism along these lines, see Doug Henry, "Does Reasonable NonBelief Exist?” Faith and Philosophy I 8 (Jan. 200 I): 8 I. I am grateful to Henry for his additional comments related to this specific issue.

88. Van Fraassen, "Peculiar Effects," I 45. I read van Fraassen's article after most of this essay had been written. Nevertheless, it provided a perspective that, while similar to my own in many ways, challenged me to rethink claims I take to be central to Augustine's account. I found the article extremely helpful in writing this section.

89. Ibid.

90. Ibid., I 54.

91. Ibid., I $52-53$.

92. Ibid., I 55 .

93. I am grateful to Steve Moroney, Douglas Henry, and Colleen McClusky for their comments on an earlier draft of this paper. 